\title{
Actions: ACRL Bocird of Directors, January 1996
}

\section{Highlights of the ACRL Board of Directors' Midwinter meetings}

\section{Programs and preconference actions Approved proposals for 1997 preconfer- ences for Rare Books \& Manuscripts Section, Instruction Section, and Western European Spe- cialists Section.}

Approved cosponsorship of Office for Literacy and Outreach Service's (OLOS) 25th anniversary program for the ALA Annual Conference in New York in name only.

Agreed to consider joint ACRI/LITA National Conference in 1999 and asked staff to inform the Board of what it would mean to undertake such an arrangement.

\section{ACRL Strategic Plan}

Received a request from the ACRL Publications Committee asking that the Strategic Plan be modified to include a strategic direction under Goal 1 "that promotes study, research, and publications relevant to academic and research librarianship"; asked that the Executive Committee develop a process to facilitate making changes to the Strategic Plan, and that the Publications Committee request be placed on the Board's agenda for consideration at Annual Conference 1996.

Reviewed the criteria for tracking progress and measuring success in implementing the ACRL Strategic Plan. The Board asked Frances Maloy and Carol Pfieffer to further refine by March 1 the six criteria which now include: member satisfaction; quality programs; addressing higher education issues; working with Washington officials; providing fiscal stability for the division; and working effectively with sections and chapters. The second draft document will be ready for an Executive Committee discus- sion during the spring Executive Committee meeting.

Reviewed draft document identifying incentives to recognize activities and programs that are aligned with the Strategic Plan.

\section{ACRL governance}

Approved the new charge and structure for the Government Relations Committee as recommended by the Government Relations/Chapters Task Force that uses chapter representatives to form a national network for addressing legislative issues.

Received recommended change in charges from the ACRL International Relations and Professional Education Committees.

Approved a change to Article XI, Rules of Order, of the ACRL Bylaws from Roberts Rules of Order to Sturgis Standard Code of Parliamentary Procedure in order to conform to the ALA change.

Approved changes to the Women's Studies Section (WSS) Bylaws, Article II, Section 1, Purpose and Section 2, Specific Responsibilities. The proposed change will appear on the spring 1996 WSS ballot.

\section{Financial actions \\ Approved fundraising guidelines for ACRL.}

Approved the transfer of $\$ \mathbf{1 0 , 0 0 0}$ from the ACRL fund balance to the ACRL endowment to be designated for the Vision for the Future Initiative. This comes out of the commitment the Board made to the Pittsburgh National Conference Executive Committee to match the revenue generated by the silent auction.

Approved increase funding of $\$ \mathbf{5 , 3 2 3}$ to support implementation of Membership Promotion and Retention Plan. 
Approved increased expenditures for the CHOICE budget in 1996 to expand the use of technology.

Approved 1997 National Conference revenue target at $10 \%$ over expenses.

Approved request from the Budget and Finance Committee that policies for funding division Annual Conference programs as part of the ACRL operating budget be established.

Voted not to pursue a membership dues increase in 1996.

Voted to establish a purpose statement for how income from ACRL endowments, established in 1990-91, will be used.

Voted to determine a mechanism that will allow members to contribute on a continuing basis to the ACRL Endowments.

\section{ACRL nominations}

Endorsed the University Libraries Section's (ULS) nomination of Hannelore Rader for a second term as ALA's representative to the IFLA
Section of the University Libraries and Other General Research Libraries.

Endorsed the Rare Books and Manuscripts Section's nomination of Henry Snyder for a second term as ALA's representative to the IFLA Section for Rare and Precious Books and Manuscripts.

\section{Liaison and publication actions}

Voted to remove AAUP from list of organizations constituting the ACRL Council of Liaisons.

Endorsed the ACRL Intellectual Freedom Committee (IFC) draft document "Electronic Access Interpretation of the Library Bill of Rights" and approved the Board's transmittal letter to the IFC stating concerns and reservations.

Endorsed the resolution from the College Libraries Section (CLS) that ALA Editions investigate publishing the fourth edition of Books for College Libraries and that ALA Editions explore expanding the scope to include all formats and materials.

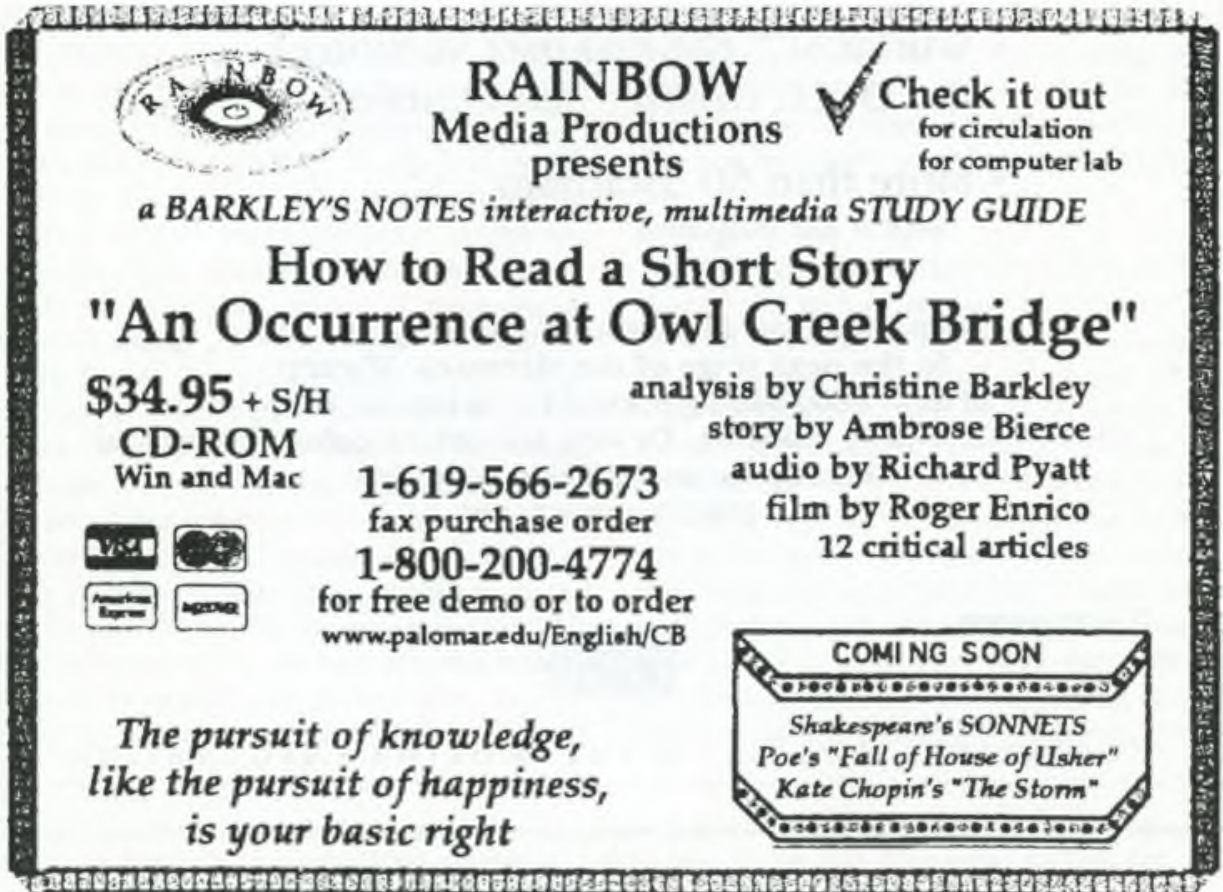



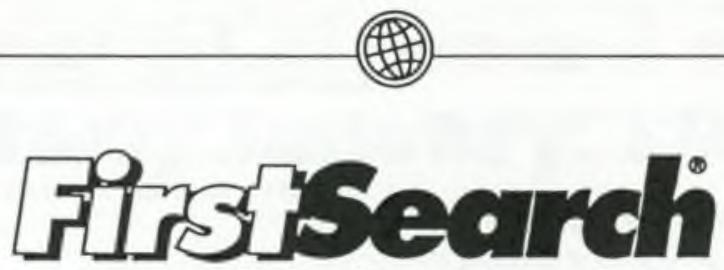

A world of information online

\section{THE FASTEST GROWING}

END-USER DATABASE SERVICE

\section{IN THE LIBRARY COMMUNITY}

- Full-text and Images* Online

- Web Access*

- NetFirst, ${ }^{\mathrm{m} *}$ the authoritative guide to Internet resources

- WorldCat,", the end-user version of the OCLC Online Union Catalog

- More than 50 databases

To find out how FirstSearch ${ }^{\oplus}$ can help you move to the next stage of the electronic library:

Call us at $1-800-848-5878$, ext. 6425 to request a copy of the new FirstSearch brochure. Or view and order it online through our home page on the World Wide Web:

bttp://www.oclc.org

"Coming soon

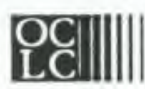

FURTHERING ACCESS TO THE W ORLD'S INFORMATION 